\title{
The fair value of the innovation. A proposal for determine it
}

\section{El valor razonable de la innovación. Una propuesta para su determinación}

\author{
RAMÍREZ-BARAJAS, Alejandro*† CARMONA-GARCÍA, Nélida and ALMANZA-SERRANO, Ma. \\ Leticia
}

Universidad Tecnológica del Suroeste de Guanajuato

ID $1^{\text {st }}$ Author: Alejandro, Ramírez-Barajas / ORC ID: 0000-0002-8426-3267, Researcher ID Thomson: S-8634-2018, CVU CONACYT ID: 228229

ID $1^{\text {st }}$ Coauthor: Nélida, Carmona-García / ORC ID: 0000-0003-0850-3668, Researcher ID Thomson: S-8608-2018, CVU CONACYT ID: 229857

ID $2^{\text {nd }}$ Coauthor: Ma. Leticia, Almanza-Serrano / ORC ID: 0000-0002-1481-5716, Researcher ID Thomson: S-8647-2018, CVU CONACYT ID: 230006

DOI: $10.35429 / J G E .2020 .7 .4 .5 .11$

Received July 17, 2020; Accepted December 15, 2020

\begin{abstract}
According to the NIF Financial Reporting Standards, fair value represents the exit price that, at the valuation date, would be received for selling an asset or paid for transferring a liability in an orderly transaction between market participants. When there is no accessible exchange value of the operation, an estimate must be made using valuation techniques. In other words, fair value is the price at which a tangible or intangible asset is sold / bought between two economic entities on a voluntary basis. Even if there are complications to determine it, it must be estimated by applying valuation techniques. But what happens when the asset object of fair value is not the subject of a transaction between two economic entities? That is, what happens when the asset is the result of an internal generation process of the economic entity, such as an industrial design on which a patent can be generated? How is fair value determined in this case? This article contains the analysis of the concept of fair value contained in the financial information standards and a proposal for its determination in the case of assets generated internally in economic entities as a result of innovation projects, considering for this purpose the valuation technique of the net present value NPV.
\end{abstract}

Fair Value, Innovation, NPV

\section{Resumen}

De acuerdo con las Normas de Información Financiera NIF, el valor razonable representa el precio de salida que, a la fecha de valuación, se recibiría por vender un activo o se pagaría por transferir un pasivo en una transacción ordenada entre participantes del mercado. Cuando no se tenga un valor de intercambio accesible de la operación debe realizarse una estimación del mismo mediante técnicas de valuación. En otras palabras, el valor razonable es el precio al que un activo tangible o intangible se vende/compra entre dos entes económicos de manera voluntaria. Mismo, que cuando existen complicaciones para determinarlo, debe estimarse aplicando técnicas de valuación. ¿Pero qué sucede cuando el activo objeto del valor razonable no es materia de una transacción entre dos entes económicos? Es decir, ¿Qué sucede cuando el activo es el resultado de un proceso de generación interna del ente económico como por ejemplo un diseño industrial sobre el cual pude generarse una patente? ¿Cómo se determina el valor razonable en este caso? El presente artículo contiene el análisis del concepto de valor razonable contenido en las normas de información financiera y una propuesta para su determinación para el caso de activos generados internamente en los entes económicos como resultado de proyectos de innovación, considerando para tal efecto la técnica de valuación del valor presente neto VPN.

Valor razonable, Innovación, VPN

Citation: RAMÍREZ-BARAJAS, Alejandro CARMONA-GARCÍA, Nélida and ALMANZA-SERRANO, Ma. Leticia. The fair value of the innovation. A proposal for determine it. RINOE Journal-General Economics. 2020. 4-7: 5-11

\footnotetext{
* Correspondence to Author (email: aramirez@utsoe.edu.mx)

$\dagger$ Researcher contributing first author.
} 


\section{Introduction}

Taking NIF C-8 INTANGIBLE ASSETS as a reference, it is possible to equate the terms intangible assets and innovation. Since the aforementioned standard recognizes as technological intangible assets, technological patents, research and development in progress, computer systems (software) and licenses, computer programs, information systems, nonpatented technology, technical knowledge, databases, plant titles, confidential formulas and processes, technical drawings, technical procedure manuals, blueprints, manufacturing process creation, procedures, and production lines. All of them are products resulting from an applied innovation process or also known as innovation project management.

In that order of ideas and without ceasing to take NIF C-8 as a reference, the innovation represented by intangible assets can reach organizations in three ways: 1) by the acquisition of an intangible asset individually, 2) by the acquisition of intangible assets through a business acquisition and 3 ) by the acquisition of an internally generated intangible asset. For any of the three cases, the value at which the acquired intangible assets must be recorded in the financial statements of the acquiring entity must be determined. For the first case, that of the acquisition of an intangible asset individually, NIF C-8 is very clear regarding the valuation of the asset: "The value of the asset will be the cash and / or cash equivalents paid by the acquired asset ". For the second case, the acquisition of an intangible asset through a business acquisition, the valuation will be the "fair value" of the asset that does not exceed the portion of the consideration paid that is attributable to it (using any of the three approaches: cost, market or income). For the third case, that of the acquisition of an internally generated intangible asset, the valuation will be the cost of the expenses made for its development.

The central theme of this article is the analysis of the third option: the acquisition of an intangible asset generated internally by the organization and the design of a proposal to assign a fair value beyond the simple determination of the cost incurred in its development. Recognizing in this way the efforts of organizations in the management of innovation projects and the risk incurred.

\section{Innovation project management.}

The management of innovation projects within organizations (or internal generation of intangible assets) has become a tool with a high degree of application in the management of innovation at different levels. The internal generation of intangible assets guarantees the solution of specific problems of the organization, taking advantage of the knowledge management of its members and the various resources available to it. However, to date, the valuation of internally generated intangible assets constitutes a dilemma that must be clarified.

On the subject of the valuation of internally generated intangible assets, NIF C-8 is quite clear. In its subsection b) of paragraph 21 it states: "the initial valuation (of an intangible asset) must be at its acquisition cost and this can be reliably determined to comply with the valuation postulate" and in numeral iii) of the same subsection Specifically for internally generated intangible assets, it states: "in the acquisition of an internally generated intangible asset, its cost is the expenses made for its development." From the foregoing, the question arises: Why for the acquisition of an intangible asset individually its valuation corresponds to the total cash or its equivalent paid (which will surely contain a profit margin over the cost of its generation) and for the acquisition of an internally generated intangible asset, its valuation will be the cost of expenditures made for its development without considering a profit margin?

For the purpose of acquiring intangible assets developed internally, not considering in their valuation a profit margin over the cost of their development represents a disincentive for the development of innovation projects within organizations. Due to the foregoing, a valuation method is proposed for the acquisition of intangible assets that considers a profit margin over the cost of their development based on the NPV net present value assessment technique. 


\section{The cost of an internally developed intangible asset}

In accordance with NIF C-8, if an organization or entity decides to generate an intangible asset internally, it must classify its efforts and corresponding expenditures in two phases or stages: a) the investigation phase; and b) the development phase. In each of these phases, the organization that develops the intangible asset must identify the corresponding costs, since for the intangible asset to be recognized as such, its cost, in addition to other requirements, must be determined "reliably". Now, regarding the costs of the investigation phase, the aforementioned rule in paragraph 53 states that these should be recognized as an expense in the period in which they are accrued.

This is because the nature of the research is such that there is not sufficient certainty that future economic benefits will be obtained as a result of the disbursements made during the research phase, which is very understandable. Regarding the expenditures made during the development phase, the sum of these must be recognized as the intangible asset as long as the entity demonstrates that it meets all the criteria that the standard sets for this purpose. In conclusion, the value at which an internally developed intangible asset must be recorded in the entity's statement of financial position will be the sum of the expenditures made in the development phase of the execution project.

\section{The "fair value" of an internally developed intangible asset}

According to NIF C-8 in its paragraph 7, the distinctive elements in the definition of an intangible asset, whether internally generated or acquired are: a) it must be identifiable, b) it must lack physical substance, c) it must provide wellexpected future economic benefits, and d) control must be had over said benefits. In that order of ideas, the ability of an internally generated intangible asset to provide wellexpected future economic benefits gives it the "right" to assign it a value greater than the mere sum of the costs incurred for its development. This "higher value" over the generation cost of the intangible asset is known as "fair value".
The same as in the glossary of the Financial Reporting Standards, it is defined as the exit price that, at the valuation date, would be received for selling an asset or paid for transferring a liability in an orderly transaction between market participants. Although, the definition contemplates the action of the sale so that the fair value of an asset exists, its absence does not prevent the entity from determining it for informational purposes only. More specifically, the Financial Reporting Standard NIF B-7 DETERMINATION OF FAIR VALUE in paragraph 41.1.2 defines it as a determination based on the market and not a specific value of an asset or a liability for the entity.

The same standard argues that for some assets and liabilities, observable market transactions or market information are available; On the other hand, for other assets and liabilities, they are not (as is the case with any intangible asset generated from an internal innovation project). However, the objective of a fair value determination in both cases is the same: to estimate the exit price at which an orderly transaction to sell the asset or to transfer the liability would be carried out between market participants at the valuation date. under current market conditions (that is, at an exit price at the valuation date from the perspective of a market participant holding the asset or owing the liability). The fair value, therefore, is based on an exchange transaction or an estimate thereof, taking into account the attributes of the item subject to be valued and the current circumstances at the time of its valuation.

Now, starting from the assumption that for internally generated intangible assets with innovative characteristics there will be no market information available to determine their fair value, the question arises how to determine it then. For the purpose of determining the fair value of an intangible asset for which there is no market information available, NIF B-7 states in paragraph 43 that an entity must use the valuation techniques that are appropriate to the circumstances and on which Sufficient inputs are available to determine fair value, maximizing the use of relevant observable inputs and minimizing the use of relevant unobservable inputs. In paragraph 44 of the aforementioned standard, it considers three types of valuation techniques according to its approach: The market approach, the cost approach and the income approach. 
The market approach is a valuation technique that uses prices and other relevant information generated by market transactions that involve identical or comparable (ie, similar) assets, liabilities, or a group of assets and liabilities. From the perspective of a market participant seller, replacement cost is the price that it would receive for the asset to be valued, based on the cost of acquisition or construction of a substitute asset of comparable utility to a market participant buyer, adjusted for the obsolescence. This is so because the market participating buyer would not pay more for the asset than the price for which it could replace the service capacity of that asset.

The income approach is a valuation technique that converts future amounts (for example, cash flows or income and expenses) into a single current amount (that is, discounted). When using the income approach, the fair value determination reflects current market expectations of those future amounts. The income approach includes the following examples:

a) present value techniques; b) option pricing models that incorporate present value techniques that reflect both the time value and the intrinsic value of an option; and c) the multiperiod surplus earnings method, which is used to determine the fair value of some intangible assets.

\section{Present value as a valuation technique and intangible assets.}

According to the Financial Reporting Standard NIF A-6 RECOGNITION AND VALUATION, the present value is the present value of future net cash flows, discounted at an appropriate discount rate, that is expected to generate an item during the normal course of operation of an entity and represents the cost of money over time, which is based on the projection of cash flows derived from the realization of an asset or the settlement of a liability. In accordance with the aforementioned standard, the present value is used to determine the following values:

\footnotetext{
a) entity or unit value to be reported;

b) incremental costs;

c) effective settlement; and

d) specific value of an asset or liability for the entity (includes value in use).
}

However, in determining the present value, two approaches are usually used: (a) expected present value and (b) estimated present value (traditional approach).

The expected present value corresponds to the future cash flows discounted at a rate riskfree and weighted by their respective probability of occurrence; This procedure incorporates, in a range of projected luxuries, the risks associated with possible variations in the amount and periodicity of cash flows. The estimated present value is the amount that is statistically the most appropriate among a range of possible amounts of projected future cash flows; Said selected flow should be discounted at a rate that incorporates the inherent risks.

Regarding the calculation of cash flows, and in accordance with NIF A-6, the following must be considered:

a) Potential cash inflows from income, arising from the use or realization of the asset or, where appropriate, from the assets that make up a reporting unit or cash-generating unit during the period or periods in which the element will remain in force To evaluate.

b) The potential cash outflows associated with the cash inflows indicated in the previous paragraph or, in the case of an individual liability, those necessary to settle it.

c) The difference between the potential cash inflows according to paragraph a) above, less the potential cash outflows directly attributable, according to paragraph $b$ ), the future net cash flows that will be reduced or increased, as the case may be. will pay or receive for the realization of assets or liabilities at the end of the estimated horizon.

Regarding the appropriate discount rate, NIF A-6 defines it as that which reflects the market conditions in which the item or item of the financial statements operates, at the time of its evaluation. Additionally, the aforementioned rule establishes that the appropriate discount rate must observe: 
a)

The return that investors demand for investments that will generate cash flows of cash in an amount, term and risk profile equivalent to those that the entity expects to obtain from the asset, reporting unit or cash-generating unit, or

b) The market rate to which the entity has access to settle its liabilities.

To estimate an appropriate discount rate that incorporates risks, the following may be taken into account, among others:

a) The entity's weighted average cost of capital,

b) The weighted average cost of capital, where applicable, of the unit to be reported or the cash-generating unit,

c) The rate at which the entity can finance itself, or

d) The rate implicit in market transactions carried out with similar assets or liabilities in other projections.

\section{Proposal for determining the fair value of the product of an internally generated innovation project.}

In order to explain how the fair value of an internally generated intangible asset would be determined using the present value technique, the steps that would be considered for this purpose are described below.

1. Description of the activities of the research stage of the innovation project, ensuring that they comply with the characteristics contemplated in NIF C-8:

a. That they are activities aimed at obtaining new knowledge;

b. To the search, evaluation and final selection of applications of the research findings or other knowledge;

c. In search of alternatives for other materials, tools, products, processes, systems or services; and

d. To the formulation, design, evaluation and final selection of possible alternatives for improvements to materials, tools, products, processes, systems or services, new or improved.
2. Determination of the estimated cost for each of the activities of the investigation phase considering for this purpose what is contemplated in NIF C-8:

a. those related to the employment of internal and external personnel dedicated to research activity;

b. the costs of materials consumed and services received in the research activity;

c. the cost of equipment and facilities that have no other alternative use other than in the specific investigation for which they are intended (net of their residual value) and the depreciation of property, plant and equipment to the extent that these assets are used for the activity research;

d. indirect costs, other than administrative costs in general, related to the research activity (these costs are allocated on a basis similar to those used to allocate indirect costs to inventories); and

e. other costs, such as the amortization of patents and licenses to the extent that these assets are used for research activity.

3. Description of the activities of the development stage of the innovation project, ensuring that they meet the characteristics contemplated in NIF C-8:

a. Activities oriented to the design, construction and testing of preproduction models and prototype and model testing;

b. To the design and manufacture of tools, templates, molds, dies and dies that involve new technology;

c. To the design, construction and operation of a pilot plant that is not of an economically feasible scale for commercial production; and

d. To the design, construction and testing of new or improved materials, tools, products, processes, systems or services.

4. Determination of the estimated cost for each of the activities of the development phase considering for this purpose what is contemplated in NIF C-8:

a. The costs related to the employment of internal and external personnel dedicated to the development activity;

b. the costs of materials and services consumed in the development activity; 
c. the depreciation of property, plant and equipment to the extent that these assets are used for development activity;

d. costs for indirect expenses, other than administrative expenses of the operation in general, related to the development activity (these costs are assigned on a basis similar to those used to assign costs for indirect expenses to inventories);

e. when capitalization is appropriate, the comprehensive financing result; and

f. other costs, such as the amortization of patents and licenses to the extent that these assets are used for development activity.

Up to this step, the cost of the research stage of the innovation project has already been estimated. Same as once the project is executed, it must be recorded as a research expense in the income statement. There is also the estimated cost of the development phase, which, if the project is executed, will be the value at which the intangible asset must be recorded in the statement of financial position.

The steps that are listed below propose the method for determining the fair value of the intangible asset in the event that the entity generating it decides to transfer its property to another between economic.

1. Estimate the entity's cash flows in the event of not developing the intangible asset.

2. Apply the Net Present Value technique to the estimated cash flows, considering for this purpose an "appropriate discount rate" determined according to NIF A-6

3. Estimate the cash flows of the entity in the event of having developed the intangible asset and accounting for the benefits of its use.

4. Apply the Net Present Value technique to the estimated cash flows.

5. Determine the difference between the net present value "without intangible assets" and the present value "with intangible assets"
6. Add to the cost of the development phase of the innovation project the difference determined in numeral 5 . The sum of both concepts will result in a reasonable value proposal based on the cost and income approaches considered in NIF B-7.

\section{Conclusions}

The proposal contemplated in this article derives from the analysis of the financial information standards NIF C-8 INTANGIBLE ASSETS, NIF B-7 DETERMINATION OF FAIR VALUE and NIF A-6 RECOGNITION AND VALUATION. The proposal is made to meet the trend of companies and organizations that have gone from the acquisition of innovative products (generally machinery and software), to the internal generation of the same; but that at the time they have made the decision to transfer their property or the rights of its use to other companies or organizations, beyond keeping the innovative product for their use and internal benefit.

At the time of writing this article, the proposal contains guidelines that must be validated by the corresponding authority. However, the proposal can become an incentive for the generation of innovative products within companies and organizations that specifically meet their operational needs. Avoiding in this way the costs associated with a low level of use of the innovation acquired by not adapting to its operational characteristics and processes.

\section{References.}

Aco, P. (2017) Los activos intangibles NIF C-8. Pp. De la diapositiva 13 a la 28 . Obtenido el 14 de abril del 2020 desde http://ri.uaemex.mx/handle/20.500.11799/7023 4

Del Río, G. C. (2012) Manual de costos, presupuestos y, adquisiciones y abastecimientos. 1era Edición. CENGAGE Learning. México

Instituto Mexicano de Contadores Públicos. (2020). Normas de Información Financiera. Consejo Mexicanao de Normas de Información financier A.C. México 
Palavecinos, B. (2011). Valor razonable: un modelo de valoración incorporado en las normas internacionales de información financiera. Obtenido el 15 de abril del 2020 desde http://www.scielo.org.co/pdf/eg/v27n118/v27n1 18a06.pdf

Reveles, L. R. (2019) Análisis de los elementos del Costo. IMCP. Universidad de Guadalajara. 2da. Edición. México. En: https://es.scribd.com/read/416316051/Analisisde-los-elementos-del-costo

Roldán, P. N. (2017) Valor presente. Obtenido el 15 de abril del 2020 desde https://economipedia.com/definiciones/valorpresente.html 